\title{
Design and Development of Game Based Learning Applications for Mathematics Learning Based on Multiple Language to Develop Verbal Capabilities
}

\author{
Muhammad Syifa'ul Qolbi, Zahid Zufar At Thaariq, Sayyidati Fatimah Az-Zahroh, M. Mahfudz \\ Anwar, Nurul Faiza \\ Universitas Negeri Malang
}

\begin{abstract}
The purpose of this research is to design an application that can help students in learning. So, the authors are interested in designing game-based mobile learning applications that have mathematical content on integer material integrated with hijaiyah numbers, so that the game media has its own uniqueness. This is due to meet the needs of game based learning in teaching and learning. This design is based on the obligation to develop numeracy skills for all citizens according to Law number 20 of 2003 concerning the national education system. In addition, there is also an obligation to understand the number of hijaiyah for Muslim citizens. The research method used uses research development. The development model used is SDLC. The stages of development consist of analysis to research design. Validation is done with results that show the attractiveness of the media with some notes. The concept in this game is like a game in general that uses this type of adventure. In the game there is a mission to solve the problem. The challenge is through hijaiyah figures provided. So this game combines mathematics with hijaiyah numbers in a portable way.
\end{abstract}

Keywords: learning media, game based learning, mathematics, multiple languages

The purpose of national education according to Law No. 20 of 2003 concerning the National Education System is to develop numeracy skills for all Indonesian people. Therefore, mathematics becomes a basis of national development. This is because mathematics is a milestone of other arithmetic, such as accounting, management, and so on. So it becomes an obligation of each educational institution in developing the following potential in students through the application of subject-based curriculum.

Subject-based curriculum is basically the same as content-based curriculum. This learning focuses on the mastery of science in certain fields. This learning can turn into leaners-centered which encourages students to learn humanistdemocratically and teaching methods that rely on lectures are replaced with context-based learning by using a variety of creative methods (Solikhah, 2015). So that the resulting output in the form of a minimum ability on the mastery of knowledge, skills, and attitudes in accordance with curriculum objectives (Haris, 2019).
Mathematics is a basic subject, in elementary school or middle school. Studying mathematics is important because in everyday life, we must not shy away from the application of mathematics, not only that mathematics is also able to develop an awareness of essential values (Siagian, 2015). Mathematics is part of a content-based curriculum. This is because students are not required to master mathematics as a whole, because mathematics is a curriculum formality. But mathematics is taught fundamentally because there are parts that are important for life.

Mathematical knowledge problems have occurred at each school in each individual. This is evidenced based on data from Jamal (2019) which says 9 out of 12 students have not been able to understand mathematics well as seen from the achievement of grades below 60 . This is supported from research conducted by Harahap \& Syarifah (2017) from qualitative data that states the results of interviews conducted with several students that can be taken as a red line that students find it difficult to 
learn mathematics, so the need for fun learning mathematics is very necessary to do.

There are factors that cause students difficulties in learning mathematics. These influencing factors are (1) factors that originate from within oneself, (2) factors that originate from the school environment, (3) factors that originate from the family, (4) factors that originate from the community (Yeni, 2017). The sensitivity of parents, the school environment, family and community is very helpful in increasing their learning motivation as early as possible, so students can still learn according to the expectations of the teacher and parents (Idris, 2017).

In addition to the sensitivity of parents, the sensitivity of learning facilities also needs to be optimized. This optimization can be done one of them by developing learning media. Learning media can be interpreted as anything that can be used to channel messages (messages), stimulate the mind, feelings, attention, and willingness of students so as to encourage the learning process (Asyhari \& Silvia, 2016). In short, learning media can be said as an intermediary for communication in learning activities (Sihkabuden, 2017). According to McKown \& Roberts (1949), there are four functions of the media, namely (1) changing the focus of formal education, (2) generating motivation to learn, (3) providing clarity and (4) providing stimulation of learning. Sihkabuden (2017) suggests factors that need to be considered in the selection of learning media, namely (1) learning objectives, (2) media effectiveness, (3) student objectives, (4) media availability and (5) procurement costs. So, considering these factors, game based learning can be a solution.

Game based learning can be described as a game environment where participants can explore their cognitive abilities to solve problems and challenge participants to achieve the game's target of learning desired (Qian \& Clark, 2016). This is as learning objectives that want to achieve the desired competencies (Kuswandi, Surahman, Thaariq \& Muthmainnah, 2018). A common motivation for using digital games to support learning is the belief that games can act as rich primers for active and deeper learning engagement with subject matter, by providing attractive and contextual settings for authentic problem solving (Gee, 2009). It is hoped that good learning games will involve players in a repetitive problem-based learning process, where players make judgments on embedded questions, experiment with solutions or strategies, interpret system feedback, reflect and adapt strategies to develop new understanding or skills (Ke, Xie, \& Xie, 2016). There are two benefits of game based learning, first, the experience game model facilitates the learning experience and this model gives students direct feedback, clear goals, and challenges (Sung, Hwang, Lin, \& Hong, 2017).

In providing material attractiveness, there is a need for integration with different knowledge groups. English is one of the family languages used as an international language. English is an international language and is used as a tool to communicate both verbally and in writing. Communicating is understanding and expressing information, thoughts, feelings, and developing science, technology, and culture (Hotimah, 2017). The reason is that English is a global language that is very instrumental in global interaction and communication along with the progress and competition of globalization. In short, understanding English as a global language should not be associated with extinction or threats and interference with native languages or mother tongues unless it is optional (Handayani, 2016).

In addition, Indonesia is the most Muslim country in the world (Qurotaa'yun, 2017). So, in increasing the adaptability of learning for Muslims it is necessary to provide content that is nuanced to Islam. One of them by providing Arabic language content in the form of hijaiyah letters. Generally in Indonesia, children will find it easier to learn their own language, that is, Indonesian in the form of sentences and vocabulary, but no less important as Muslims is to learn Arabic letters in Arabic because it is the beginning of knowledge in learning sentence language. Arabic and also equipped in fluently reading the Qur'an and its punctuation marks (Yudhistira \& Widiarina, 2019).

Therefore, the authors are interested in designing game-based learning applications with mathematics in hijaiyah. This application is a development of mathematics learning that can be played in an interesting and fun way. It is hoped that 
this game can provide cognitive changes to students indirectly.

\section{METHODS}

In this research, the system using the SDLC (System Development Life Cycle) method, with the Waterfall model (Sommerville, 2011). According to Rossa \& Shalahuddin (2011) SDLC or Software Development Life Cycle is the process of developing or changing a software system by using models and methodologies that people use to develop previous software systems. This method is divided into three stages, namely the analysis and definition of requirements, system design and unit testing. In this article discusses two stages of development.

In the analysis and definition of requirements, the authors seek to study the problem through a literature study. This study was obtained through journals and proceedings. After that, the right solution for the problem is formulated through direct writing.

At the system design stage, the authors make the system design in the form of story boards, determine images and sounds and determine the effects. In this case the author arrived at the stage of making interface design. The interface design was designed using Adobe Illustrator.

\section{RESULT}

The results of this research are in the form of interface design of this math game. This interface design was developed using the principles of the game in it.

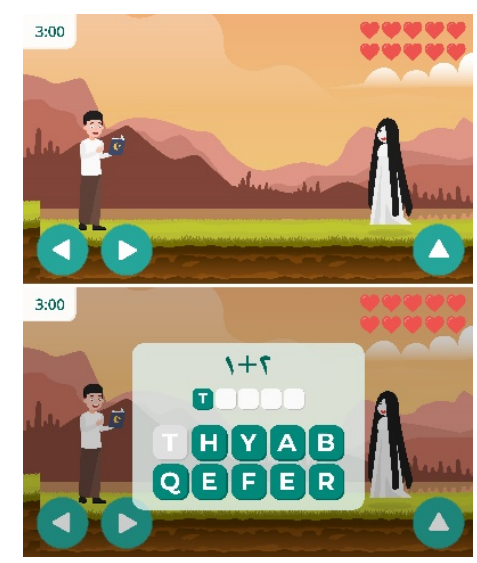

Picture 1. Interface Screen
In the display picture 1 illustrates the atmosphere in the game. Seen in the picture is a pious young man who is diligent in reading the Qur'an. But the young man was blocked by a ghost like in the picture. So, to defeat the ghost, a question appeared that contained hijaiyah numbers and had to be answered in English. This indirectly trains the verbal ability of the child's vocabulary

\section{MAT JAI MATHKMATIßS HIJAIYAH}

\section{Picture 2. Logo game}

In the picture 2 display above is the logo of this game. Creating a visual identity is one way to build a physical brand that is very important. And one of the main elements in creating a visual identity is the logo. According to Milton Glaser, a logo is an entrance that reflects a brand. Logos can reflect the face, and personality of an entity (Oscario, 2013). The validation results show the attractiveness of the game with notes such as the need for further development.

\section{DISSCUSION}

This game is part of a game based learning that provides the concept of playing while learning. The learning process must be in a pleasant atmosphere so that children can feel happy in participating in learning activities (Cahyono, 2017). So that in essence is play-oriented learning (play while learning), development-oriented learning which gives more opportunities for children to be able to learn in appropriate ways (Rozalena \& Kristiawan, 2017). Designing one of the objectives is to provide effective learning that is processed through information obtained by students (Chabib, Djatmika, \& Kuswandi, 2017).

In an effort to provide portable game-based learning services, the use of mobile learning is very influential. Mobile learning is an innovation in the field of learning, which allows a more flexible learning process, because learning does not always learn in the classroom or in the laboratory. In the context of learning, mobile learning acts as a 
learning system, learning media or source of learning material (Surahman \& Alfindasari, 2017). In this case, learning can be done anywhere and anytime (Surahman, 2019; Surahman \& Surjono, 2017). This strategy can make it easier for students to master the material as a whole (Lytras et al., 2008; Rekkedal \& Dye, 2007).

Experts have discovered that educational software games help students to understand mathematics and can improve their performance (Hawkins, Collins, Hernan, \& Flowers, 2017; Kadosh, Dowker, Heine, Kaufmann, \& Kucian, 2013; Ninaus, Kiili, McMullen, \& Moeller, 2017; ter Vrugte et al., 2017; Van de Weijer-Bergsma, Kroesbergen, Jolani, \& Van Luit, 2016). Research related to mobile learning shows as many as 20 valid answer sheets for the questionnaire obtained from 20 students in the experimental group. To analyze the questionnaire, this study used a five-point Likert scale, anchored at the end point: "strongly disagree" and "strongly agree". to assess the internal consistency of the survey adopted and values exceeding 0.73 in all dimensions, which shows the satisfactory level of satisfaction of the items (Hwang, Shih, Ma, Shadiev, \& Chen, 2016). Other research also mentions the results of the survey found that technology-based games are useful in the process of learning and teaching in schools (Koh, Kin, Wadhwa, \& Lim, 2012).

The material provided in this mobile learning game is mathematics. Because mathematics plays a role in almost every aspect even in today's technological and digital times (Siregar, 2017). In the initial paragraph of the National Research Council (1989) report that mathematics is the key to opportunity, not only to language, but nowadays mathematics contributes directly and fundamentally to business, finance, health and defense. So that mathematical skills is one aspect that students must master (Hadi, 2013).

In addition to the mathematical skills provided, verbal skills through language are also provided in the content of this game. Verbal ability must be based on data or information obtained from the many possible answers to a problem, the emphasis lies in the quantity, accuracy, and diversity of one's answers (Magdalena, Mulyani, \& Van Hayus, 2014). Students with good verbal skills will easily grasp the material, especially in mathematical material (Hidayah, 2019)

In the provision of material contained in the game, there is continuity in the ability to be obtained in terms of language. This is commonly called multiple language. Multiple language or multilingual is the use of vocabulary that exceeds one language. Multilingual languages can usually be guided to reflect on and utilize their multi-language learning in setting clear, challenging and attainable goals for themselves (Singleton \& Aronin, 2007).

Therefore, the hope of this design is to be able to become a game based learning that can practice the ability of multiple languages through mathematical material in an interesting and fun way. So, it can indirectly build learning experiences of learners constructively.

\section{CONCLUSION}

The problem of learning mathematics for students lies in the material presented. This is what makes students difficult when learning mathematics. Mathematics is the basic science of current developments. Supported by good language skills, so mathematics needs to be studied in full. So, the authors are interested in designing game-based learning applications on mathematical material based on multiple languages that are good for student learning. Through this game, students can independently learn anytime and anywhere. So students are able to achieve cognitive improvement that is their competence.

\section{REFFERENCE}

Asyhari, A., \& Silvia, H. (2016). Pengembangan Media Pembelajaran Berupa Buletin dalam Bentuk Buku Saku untuk Pembelajran IPA Terpadu. Jurnal Ilmiah Pendidikan Fisika Al-Biruni, 5(1), $1-13$.

Cahyono, A. (2017). Meningkatkan Kemampuan Berhitung Menggunakan Media Belajar Ular Tangga Di Taman Kanak-Kanak Dharma Wanita 2 Jragan Tembarak Temanggung. EJurnal Skripsi Program Studi Teknologi Pendidikan, 6(5), 423-430.

Chabib, M., Djatmika, E. T., \& Kuswandi, D. (2017). Efektivitas Pengembangan Media Permainan Ular Tangga sebagai Sarana Belajar Tematik 
SD. Jurnal Pendidikan: Teori, Penelitian, Dan Pengembangan, 2(7), 910-918.

Gee, J. P. (2009). Deep learning properties of good digital games: How far can they go? In Serious games: Mechanisms and effects. London \& New York: Routledge.

Hadi, M. R. (2013). Pengembangan Media Pembelajaran Travel Game untuk Mengembangkan Keterampilan Siswa SMP Kelas VII pada Materi Garis dan Sudut (Skripsi). Universitas Negeri Malang, Malang.

Handayani, S. (2016). Pentingnya Kemampuan Berbahasa Inggris Sebagai Dalam Menyongsong ASEAN Community 2015. Jurnal Profesi Pendidik, 3(1).

Harahap, D. H., \& Syarifah, R. (2017). Studi kasus kesulitan belajar matematika pada remaja. Jurnal Psikologi, 11(1).

Haris, A. (2019). Penerapan Kurikulum Berbasis KKNI Pada Program Studi Pendidikan Agama Islam. AL-FURQAN, 7(2), 63-81.

Hawkins, R. O., Collins, T., Hernan, C., \& Flowers, E. (2017). Using computer-assisted instruction to build math fact fluency: An implementation guide. Intervention in School and Clinic, 52(3), 141-147.

Hidayah, N. (2019). Kecerdasan Verbal-Linguistik Siswa dalam Menyelesaikan Masalah Teorema Pythagoras Ditinjau dari Kemampuan Matematika (Skripsi). IAIN Tulungagung, Tulungagung.

Hotimah, E. (2017). Penggunaan media flashcard dalam meningkatkan kemampuan siswa pada pembelajaran kosakata bahasa Inggris kelas II MI Ar-Rochman Samarang Garut. Jurnal Pendidikan UNIGA, 4(1), 10-18.

Hwang, W.-Y., Shih, T. K., Ma, Z.-H., Shadiev, R., \& Chen, S.-Y. (2016). Evaluating listening and speaking skills in a mobile game-based learning environment with situational contexts. Computer Assisted Language Learning, 29(4), 639-657.

Idris, R. (2017). Mengatasi kesulitan belajar dengan pendekatan psikologi kognitif. Lentera Pendidikan: Jurnal Ilmu Tarbiyah Dan Keguruan, 12(2), 152-172.

Jamal, F. (2019). Analisis Kesulitan Belajar Siswa dalam Mata Pelajaran Matematika Pada Materi
Peluang Kelas XI IPA SMA Muhammadiyah Meulaboh Johan Pahlawan. MAJU: Jurnal Ilmiah Pendidikan Matematika, 1(1).

Kadosh, R. C., Dowker, A., Heine, A., Kaufmann, L., \& Kucian, K. (2013). Interventions for improving numerical abilities: Present and future. Trends in Neuroscience and Education, 2(2), 85-93.

Ke, F., Xie, K., \& Xie, Y. (2016). Game-based learning engagement: A theory-and data-driven exploration. British Journal of Educational Technology, 47(6), 1183-1201.

Koh, E., Kin, Y. G., Wadhwa, B., \& Lim, J. (2012). Teacher perceptions of games in Singapore schools. Simulation \& Gaming, 43(1), 51-66.

Kuswandi, D., Surahman, E., Thaariq, Z. Z. A., \& Muthmainnah, M. (2018). K-Means Clustering of Student Perceptions on Project-Based Learning Model Application. 2018 4th International Conference on Education and Technology (ICET), 9-12. IEEE.

Lytras, M. D., Carroll, J. M., Damiani, E., Tennyson, R. D., Avison, D., Vossen, G., \& de Pablos, P. O. (2008). The open knowledge society: A computer science and information systems manifesto (Vol. 19). Springer Science \& Business Media.

Magdalena, O., Mulyani, S., \& Van Hayus, E. S. (2014). Pengaruh pembelajaran model problem based learning dan inquiry terhadap prestasi belajar siswa ditinjau dari kreativitas verbal pada materi hukum dasar kimia kelas X SMAN 1 Boyolali tahun pelajaran 2013/2014. Jurnal Pendidikan Kimia, 3(4), 162-169.

McKown, H. C., \& Roberts, A. B. (1949). Audio-visual aids to instruction. New York: McGraw-Hill book Co., Inc.

National Research Council. (1989). Everybody counts: A report to the nation on the future of mathematics education. Washington: National Academies Press.

Ninaus, M., Kiili, K., McMullen, J., \& Moeller, K. (2017). Assessing fraction knowledge by a digital game. Computers in Human Behavior, 70, 197-206.

Oscario, A. (2013). Pentingnya Peran Logo Dalam Membangun Brand. Humaniora, 4(1), 191-202.

Qian, M., \& Clark, K. R. (2016). Game-based Learning and 21 st century skills: A review of recent 
research. Computers in Human Behavior, 63, $50-58$.

Qurotaa'yun, Q. Q. (2017). Analisis Framing Model Zhongdang Pan dan Gerald M. Kosicky terhadap Kasus Bom Thamrin pada Pemberitaan Media Asing Online CNN (Cable News Network) Periode Januari 2016 (Skripsi). Universitas Muhammadiyah Yogyakarta, Yogyakarta.

Rekkedal, T., \& Dye, A. (2007). Mobile Distance Learning with PDAs: Development and testing of pedagogical and system solutions supporting mobile distance learners. The International Review of Research in Open and Distributed Learning, 8(2).

Rossa, S. A., \& Shalahuddin. (2011). Modul Pembelajaran Rekayasa PerangkatLunak (Terstruktur dan Berorientasi Objek). Bandung: Modula.

Rozalena, R., \& Kristiawan, M. (2017). Pengelolaan Pembelajaran Paud dalam Mengembangkan Potensi Anak Usia Dini. JMKSP (Jurnal Manajemen, Kepemimpinan, Dan Supervisi Pendidikan), 2(1).

Siagian, R. E. F. (2015). Pengaruh minat dan kebiasaan belajar siswa terrhadap prestasi belajar matematika. Formatif: Jurnal Ilmiah Pendidikan MIPA, 2(2).

Sihkabuden. (2017). Media Pembelajaran. Malang: Tidak Diterbitkan.

Singleton, D., \& Aronin, L. (2007). Multiple language learning in the light of the theory of affordances. International Journal of Innovation in Language Learning and Teaching, 1(1), 83-96.

Siregar, N. R. (2017). Persepsi siswa pada pelajaran matematika: Studi pendahuluan pada siswa yang menyenangi game. Prosiding Temu Ilmiah Nasional X Ikatan Psikologi Perkembangan Indonesia, 1 .

Solikhah, I. (2015). KKNI dalam Kurikulum Berbasis Learning Outcomes. LINGUA: Journal of Language, Literature and Teaching, 12(1), 122.

Sommerville, I. (2011). Software engineering. Boston: Addison-wesley.
Sung, H.-Y., Hwang, G.-J., Lin, C.-J., \& Hong, T.-W. (2017). Experiencing the Analects of Confucius: An experiential game-based learning approach to promoting students' motivation and conception of learning. Computers \& Education, 110, 143-153.

Surahman, E. (2019). Integrated Mobile Learning System (IMOLES) sebagai Upaya Mewujudkan Masyarakat Pebelajar Unggul Era Digital. JINOTEP (Jurnal Inovasi Dan Teknologi Pembelajaran) Kajian Dan Riset Dalam Teknologi Pembelajaran, 5(2), 50-56.

Surahman, E., \& Alfindasari, D. (2017). Developing Adaptive Mobile Learning with the Principle of Coherence Mayer on Biology Subjects of High School to Support the Open and Distance Education. 3rd International Conference on Education and Training (ICET 2017). Atlantis Press.

Surahman, E., \& Surjono, H. D. (2017). Pengembangan adaptive mobile learning pada mata pelajaran biologi SMA sebagai upaya mendukung proses blended learning. Jurnal Inovasi Teknologi Pendidikan, 4(1), 26-37.

ter Vrugte, J., de Jong, T., Vandercruysse, S., Wouters, P., van Oostendorp, H., \& Elen, J. (2017). Computer game-based mathematics education: Embedded faded worked examples facilitate knowledge acquisition. Learning and Instruction, 50, 44-53.

Undang Undang Nomor 20 tahun 2003 tentang Sistem Pendidikan Nasional. (2003).

Van de Weijer-Bergsma, E., Kroesbergen, E. H., Jolani, S., \& Van Luit, J. E. (2016). The Monkey game: A computerized verbal working memory task for self-reliant administration in primary school children. Behavior Research Methods, 48(2), 756-771.

Yeni, E. M. (2017). Kesulitan Belajar Matematika Di Sekolah Dasar. Jurnal Pendidikan Dasar (JUPENDAS), 2(2).

Yudhistira, R. J., \& Widiarina, W. (2019). Animasi Interaktif Pengenalan Huruf Hijaiyah Berbasis Android. Jurnal Teknik Komputer, 5(1), 65-70. 